Koch and Kossowitsch's experiments, make it impossible to deny that the above hypothesis as to the powers of the protoplasmic machinery may apply to the cells of some lower organisms, without symbiosis coming into play at all. The remarkable facts brought to light regarding sulphur-bacteria and iron-bacteria by Winogradsky, and the still more unexpected results this observer obtained with nitrifying organisms, show that the machinery of the cell can avail itself of sources of energy undreamt of by earlier observers. If, by the oxidation of sulphur or sulphuretted hydrogen, or of lower iron-compounds, or of ammonia, certain of these organisms can obtain the energy necessary to set going machinery capable of so presenting other molecules of the elements they take up to one another that organic compounds result, it is by no means inconceivable that, at the cost of carbon-compounds which they oxidise powerfully, the necessary energy can be obtained to force even free nitrogen into combinations.

It is equally conceivable that in the case of the leguminose, the symbiotic organism is really more of a parasite (it is necessarily a parasite in some degree) than is assumed in the third view, and that, at the expense of the carbo-hydrates so richly furnished to it by the host plant, the fungoid organism alone supplies the machinery for forcing the nitrogen into combination, and that when it has stored up relatively large quantities, owing to its activity in the incubators-the root-nodules-provided for it by its host-plant, and is diminishing in resisting power, the latter at length turns round and absorbs the stores.

The chief objection to this view is that the gains in total nitrogen seem to be greater than would be thus explained, unless the organisms in the soil outside the roots are also fixing free nitrogen.

Such then, put too shortly as regards the numerous experimental facts, are some of the chief ideas agitating the scientific world on this question, a question which, be it emphatically stated, promises to be of more importance to agriculture in the future than any legislation as to prices, \&c. that we can conceive ; for if it turns out that the acquisition of free nitrogen by the land, or, what amounts to the same thing, the plants growing on it, can be economically promoted, the farmer and forester may have the control of sources of real wealth not yet dreamt of. Unquestionably there is an enormous amount of careful and very difficult experimental work to be done before we arrive at the solution of the various vital questions raised; but the as tounding results obtained during the last decade by a few earnest workers promise brilliant results in the future.

H. Marshall Ward.

\section{THE HAR DALAM CAVERN AND ITS OSSIFEROUS CONTENTS.}

$\mathrm{I}^{\mathrm{T}}$ is now about half a century since Admiral Spratt first recorded the discovery of the Maltese ossiferous cavern deposits in which, at a later period, Prof. Leith Adams found so remarkable an assemblage of mammalian and other remains.

The fauna which was then brought to light was of a most unique and interesting character, consisting of three species of elephants, one of which $E$. falconeri was, when full grown, no larger than an average size Newfoundland dog; two species of hippopotamus, one $H$. minutus, about the size of a small donkey, several species of gigantic swans, large dormice, land tortoises, cranes, vultures, \&c.

These remarkable discoveries in an area so circumscribed attracted much attention in the scientific world, and considerable interest was evinced in them; and this the more so as that Dr. Falconer was at that time engaged in determining certain organic remains which had been found in similar deposits, and under similar conditions, in Sicily. The result of the explorations in the two islands was to demonstrate that Malta had, at no very remote period, been directly in connection with the continental areas on the European side, and indirectly with those of Africa. Brilliant, however, as were the discoveries made by Spratt and Adams, many difficulties of vital interest to the archæologist, the geologist, and the physical geographer were left unsolved when Adams departed from these islands in 1872 . Dr. Caruana, a Maltese archæologist, then carried on the work for a short time, but finally abandoned it; and from that time to the arrival of Dr. John Murray, in I889, nothing further was done. In that and the following year, Dr. Murray undertook a thorough investigation into the marine strata of the islands, and recognising the value of the work that still remained to be done in the Pleistocene beds, he urged the desirability of a careful examination of them being made. Several interesting discoveries of Pleistocene deposits had already been made by Mr. John H. Cooke, in the island of Gozo; and accordingly, at the suggestion of Dr. John Murray, and with the assistance of the Royal Society, Mr. Cooke undertook to carry on the work.

In the spring of 1892 the excavation of a large cavern situate in the Har Dalam Gorge was commenced, the results of which have materially assisted in clearing up many of the more debatable problems which had been left unsolved by previous workers. These results have been embodied, by Mr. Cooke, in a memoir which was communicated to the Royal Society.

The gorge in question is one of many gorges of erosion, which are to be found in the low-lying and denuded areas of Malta and Gozo. It is situated in the eastern part of Malta, and debouches on the broad, extensive bay of Marsa Scirocco. It forms the drainage channel of a catchment basin of considerable area, but owing to the very small annual rainfall of the islands the stream that now courses through it for a few occasional hours in the winter season is insignificant in size, and impotent as an eroding agent.

But it was not always so. The rounded boulders, the water. worm debris, and the curvilinear undercuttings with which the sides of the gorge are scored, as well as the character of the caves in the vicinity and of their deposits, all attest to the former action of torrential volumes of water such as could only have been formed during the existence of climatic conditions of a much more severe and humid nature than those that now endure. The cavern, which has been named after the gorge in which it occurs, is situated 500 yards from the shore on the northern side of the gorge, and consists of a main gallery, 400 feet in length, when it ramifies in various directions, forming smaller tunnels and chambers, which follow the jointings and beddling planes of the rock. One branch fissure is 250 feet in length, 15 feet high, and just wide enough for a man to pass along it, widening out at intervals into dome-shaped rock chambers.

Two of the other galleries are of considerable height, but do not exceed 20 feet in length; and they were filled with débris to within $\mathrm{I} \mathrm{ft}$. 6 in. to $2 \mathrm{ft}$. of the roof with a reddish plastic clay, kept moist by percolation from the roof, the sides of all the galleries being encrusted with a stalactitic lining.

The mouth of the main gallery is 26 feet wide and 10 feet high, and has been used during late years as a cattle shelter, the entrance being walled up and provided with a doorway. It widens inwards into a spacious chamber, 60 feet wide and 17 feet high, having a branch on the right hand, which was filled to the roof with alluvial soil and boulders.

The roof of the cavern was formerly covered with stalactites, but most of them have been broken off by the action of the torrents that invaded the cave, and they were afterwards buried in the floor deposits.

These stalactites and their corresponding stalagmitic bosses were observed at three different levels, each being covered by fresh alluvial deposits, indicating the intermittent character of the floods that invaded the cavern and the long periods that elapsed between them.

The deposits met with vary considerably in different parts of the cave. At the furthest extremity they are mainly composed of red loam ; in the middle of large boulders, broken stalactites, and old pottery enclosed in clay; towards the entrance of a grey indurated marl with abundant remains of land shells, roots of plants, bones of deer, and boulders.

The cave is everywhere strewn with enormous quantities of waterworn boulders, similar to those met with so abundantly in the valleys and gorges of the islands.

From the differential characters exhibited by the earlier and later layers, it was evident that the deposits belonged to two distinct epochs, each of which was characterised by a special fauna.

In the lower series were found the remains of Ursus (arctos?), Elephas mnadransis, Hippopotami pentlandi, Canis (equalling a wolf in size), Cervus elaphus, var. barbarus, and Human remains; while the upper series was found to abound in the remains of man and domestic animals-pig, goat, sheep, bos, small land chelonian, and.Cervus elephus, var. barbarus.

The discovery of the carnivoræ was specially significant. As early as 1859 Spratt had observed that many of the bones that

NO. I 274 , vOL. 49] 
he had exhumed bore traces of having been gnawed; and later on Adams made similar observations.

Notwithstanding, however, the most diligent research exiending over a period of twenty years, no further evidences of the presence of carnivoræ were forthcoming. These were the first remains met with.

Equally interesting was the discovery which was made in Trench v. Among the remains which were exhumed $\mathrm{Mr}$. Arthur Smith Woodward has determined the third metacarpal of man. It was found at a depth of $3 \mathrm{ft}$. $6 \mathrm{in}$. from the surface, and underlying a layer containing pottery. It is probably of great antiquity, having been extracted from one of the earliest layers in the cavern.

That these deposits are of great antiquity there can be no doubt. The state of mineralisation in which the bones were found was most complete; and when, in addition to this, the height of forty feet above the gorge bed at which the cavern is at present situated be considered, in conjunction with the extremely slow and gradual character of the processes of erosion which were engaged in cutting down the bed of the gorge to its present level--when these, and the other equally important points regarding the great changes in climate that have taken place between this and then be duly weighed, the author thinks that he would be justified in referring the Har Dalam deposits to a considerably remote epoch.

Such then in brief are a few of the evidences bearing on the prehistoric history of the Maltese Islands which these excavations have supplied us with-evidences which have added one more arch to the bridge with which the geologist and the archæologist in the Maltese Islands are endeavouring to span the gulf which at present divides their labours.

\section{GEOGRAPHY IN CAUCASUS.}

$A$ RECENT volume of the Memoirs (Zapiski) of the Caucasian Branch of the Russian Geographical Society (vol. xv.) is of more than usual interest. It opens with a paper, by Mr. Konshin, on the old beds of the Amu-daria, accompanied by a map which shows the consecutive decrease of the area of the Caspian sea since the beginning of the Post-Pliocene epoch. It is known that the Russian geologist was first to point out that what had been previously described as old beds of the Amu are not beds at all, but elongated channels occupied once by the salt waters of the Caspian. The writers of antiquity were not wrong in representing the Caspian sea as a basin, elongated from west to east, and in ignoring the existence of Lake Aral as a lake separated from the Caspian. At the beginning of the Post-Pliocene epoch, and perhaps later on as well, the Caspian sent eastward two wide gulfs, one of which reached the longitude of Merv, and covered what is now a depression in the south of the Kara-kum elevated plain ; while another gulf, stretching north-eastwards, included Lake Aral and what is now the deIta of the Amu, as far as Khiva and Pitnyak. Thus, it was not the Amu which reached the Caspian, but the sea which reached the river by extending much further eastward than it does now. The Chink, which has so often been described as an old bed of the Amu, was the northern coast of the Kara-kum gulf; while the river-like beds of the Sary-kamysh depression were narrow channels through which the waters of Lake Aral occasionally found their way into the Caspian, long time after the two great lakes had been separated from each other. Mr. Konshin's little map very well illustrates the subsequent changes of the form of the Caspian. It may only be added that an exploration of the Ust-urt, and especially of the chain of lakes which crosses it from west to east-connecting, so to say, the Caspian with Lake Aral-is extremely desirable; it seems very probable that another channel of communication between the two great lakes will be discovered in that direction as well. A. V. Pastukhoff's communication about his ascension on the Elbrus and the Khalatsa peak, in July, I890, is also full of interest, and is accompanied by excellent photographs and a map. On the top of this latter peak, which reaches I 1 , 915 feet, the party was overtaken by a snowstorm, during which they were surrounded by a most beautiful display of electric fires; all their fur coats, their hair, their moustaches, as well as the poles of their tents and all metallic things, were enveloped in luminous discharges, which came to an end only after a discharge of thunder. The thunderstorm was terrible, especially one discharge of globular thunder, which rendered all the party senseless for a time.
Dr. Dinnik's descriptions of his journey in Western Ossetia, as well as in Pshavia and Khevsuria, are full of vaiuable observations, especially as regards glaciers and traces of an extensive previous glaciation of the main chain. And Mr. Filipoff's remarks relative to the present changes of level in the Caspian, show that the level of the sea is continually oscillating in its dif ferent parts, and never remains quite horizontal; it depends very much upon the different winds.

Mr. N. Alboff's reports of his botanical explorations in Abhasia and Lazistan are most valuable, the more so as his conclusions relative to the flora of West Caucasus, very different from those arrived at by MM. Krasnoff and Kuznetsoff, are based on most elaborate studies and extensive collections.

Another important paper is contributed to the same volume by $\mathrm{K}$. N. Rossikoff, on the desiccation of lakes on the northern slope of Caucasus. These lakes belong to three different categories. Those on the coasts of both the Caspian sea and the sea of Azov have originated from old lagunæ, or in the deltas of the rivers. They attain but a small depth. $\left(3 \frac{1}{2}\right.$ fathoms is the maximum depth observed), and many of them are brackish. The lakes of the Steppe-region occupy distinct depressions of the surface, and are fed by little temporary streams and underground water. And, finally, there is a small number of lakes at the footings of the Main Ridge and in the mountain region itself. Now, all the lakes relative to which there are reliable observations made during the years $188 \mathrm{I}$ to $\mathrm{I} 89 \mathrm{I}$, are decidedly in a period of desiccation. Most of the lakes of the Stepperegion have either entirely disappeared, or are living the last years of their existence ; they will exist no more in a few years. The lakes scattered at the foot of the mountains are also in decrease ; their levels have sunk during the last eight years of the above period by an average of ninety inches. As to the lakes of the mountain region, their desiccation seems chiefly to depend upon the destruction of forests. These facts entirely confirm the widely-spread belief that the climate of Caucasus is becoming more and more dry during the last forty or fifty years.

The volume is concluded with an extensive paper by Dr. Pantyukhoff, full of most valuable anthropological measurements of representatives of the various nationalities and tribes of Caucasus, and accompanied by many engravings.

\section{ISOPERIMETRICAL PROBLEMS. ${ }^{1}$}

\author{
Dido, B.C. 800 or 900 . \\ Horatius Cocles, B.C. 508. \\ Pappus, Buok v. A.v. 390. \\ John Bernoulli, A. D. I700. \\ Euler, A.D. 1744 \\ Maupertuis (Least Action), b. 1698, d. 1759 \\ Lagrange (Calculus of Variations), 1759 . \\ Hamilton (Actional Equations of Dynamics), 1834 \\ Liouville, 1840 to 1860 .
}

THE first isoperimetrical problem known in history was practically solved by Dido, a clever Phœenician princess, who left her Tyrian home and emigrated to North Africa, with all her property and a large retinue, because her brother Pygmalion murdered her rich uncle and husbani Acerbas, and plotted to defraud her of the money which he left. On landing in a bay about the middle of the north coast of Africa she obtained a grant from Hiarbas, the native chief of the district, of as much land as she could enclose with an ox-hide. She cut the ox-hide into an exceedingly long strip, and succeeded in enclosing bet ween it and the sea a very valuable territory ${ }^{2}$ on which she built Carthage.

The next isoperimetrical problem on record was three or four hundred years later, when Horatius Cocles, after saving his country by defending the bridge until it was destroyed by the Romans behind him, saved his own life and got back into Rome by swimming the Tiber under the broken bridge, and was rewarded by his grateful countrymen with a grant of as much land as he could plough round in a day.

In Dido's problem the greatest value of land was to be enclosed by a line of given length. If the land is all of equal value the general solution of the problem shows that her line of ox-hide should be laid down in a circle. It shows also that if the sea is to be part of the boundary, starting, let us say, south.

1 A lecture delivered at the Royal Institution, May 12, x893, by Lord Kelvin. Pres. R.S.

2 Called Byrsa, from Bú $\rho \sigma \alpha$, the hide of a bull. (Smith's "Dictionary of Greek and Roman Biography and Mythology," article "Dido.")

NO. I 274 , VOL. 49] 